\title{
ARTYKUtY RECENZYJNE
}

\section{Krzysztof Gawlikowski}

\section{WPROWADZENIE DO CHIŃSKIEJ KULTURY LITERACKIEJ}

Piotr Plebaniak, Starożytna mądrość chińska w sentencjach, PWN, Warszawa 2010, ss. 235.

Bardzo dobrze, że ukazała się praca, jakiej wyraźnie brakowało na naszym rynku wydawniczym. Wprowadza ona znakomicie do chińskiej kultury literackiej oraz intelektualnej, a ponadto została pięknie wydana, z wysmakowaną i dużej urody szatą graficzną. Reprezentuje także rzadki u nas typ publikacji: jest pracą popularną, napisaną w sposób przystępny i zajmujący, a zarazem rzetelny naukowo.

Jest to pierwsza tego typu praca przygotowana w Polsce, chociaż w Chinach podobnych wydawnictw prezentujących przysłowia jest wiele; oczywiście tam mają one trochę inny charakter. W Polsce ukazywały się wprawdzie zbiory przysłów orientalnych, lecz były to mniej czy bardziej udane przekłady jedynie samych przysłów. Piotr Plebaniak daje natomiast przekład frazy chińskiej, opis jej znaczenia i użycia, czasem z odwołaniem do znanych polityków współczesnych, którzy jej używali. Zazwyczaj towarzyszy temu opis tradycyjnie podawanego jej pochodzenia (zdarzenia historycznego, sceny z dzieła literackiego, dzieła klasycznego czy sytuacji, kiedy po raz pierwszy pojawiło się dane sformułowanie, nieraz później modyfikowane). Na dole autor podaje pierwsze źródło literackie zawierające zapis tej frazy, z przekładem polskim jego tytułu i z przybliżonym datowaniem, a obydwie te kwestie nie są proste, gdyż mamy do czynienia najczęściej z dziełami liczącymi kilkaset, albo nawet kilka tysięcy lat, w tym również mniej znanymi.

Zazwyczaj przedstawieniu frazy poświęcona jest jedna strona, a obok podawane są dodatkowe objaśnienia. Autor podaje też zawsze hieroglificzny zapis chiński sentencji oraz jej transkrypcję w alfabecie łacińskim (z zaznaczeniem tonów). Dla osoby znającej język, albo uczącej się go, jest to bardzo cenne. Nieraz przekład 
może być kontrowersyjny - ze względu na obfitość w języku chińskim terminów wieloznacznych wiele fraz można tłumaczyć na różne sposoby.

Trzeba dodać, że wszystkie nazwy i terminy chińskie podawane są znakami chińskimi, w obowiązującej transkrypcji piyin, z dodanym thumaczeniem polskim. Dotyczy to nie tylko samych przysłów, ale także tytułów dzieł chińskich, a nawet materiału ilustracyjnego - nazwisk malarzy, tytułów ich prac czy nazw na mapach. Czasami autor przedstawia ewolucję poszczególnych znaków chińskich od form archaicznych do używanych współcześnie (niestety bez dodatkowych objaśnień, więc czytelnik nie dowiaduje się, co dane elementy przedstawiają, chociaż wprowadzenie takich objaśnień mogłoby okazać się trudne dla laika). Poszczególne znaki i całe frazy pojawiają się także w tekście w formie inskrypcji kaligraficznych - zdobiąc tekst i wzbogacając go o swoistą aurę literacką. Jeśli padnie pytanie: po co te hieroglify, kiedy prawie nikt w Polsce ich nie zna! - odpowiedzieć na nie łatwo: współcześnie stało się to standardem na Zachodzie w porządnych publikacjach. Wprawdzie tam chińskiego uczą się dzisiaj już tysiące ludzi, wprowadza się go nawet do szkół, a w Polsce ledwo setki, lecz niewątpliwie i u nas jego znajomość będzie się poszerzała. Można by więc stwierdzić, że książka wprowadza u nas standardy połowy XXI w. Ponadto, jak zostało powiedziane, użycie znaków przypomina czytelnikowi, że to nimi zapisywano wszystkie teksty, a tu mamy do czynienia tylko z ich przekładami. Wnoszą też one specyficzne walory estetyczne, tworzą pewien klimat i oswajają z pismem, którym posługuje się prawie jedna trzecia ludzkości. U nas zaś jest ono wciąż tak egzotyczne, że nawet na murach nowej Biblioteki Uniwersytetu Warszawskiego, gdzie umieszczono przykłady różnych ,pism egzotycznych”, a nawet zapis nutowy, znaki chińskie pominięto, choć to w nich właśnie zapisano literaturę wielekroć obszerniejszą od całej literatury Zachodu!

Pracę Plebaniaka różni od publikacji poprzedników również o wiele szersze spektrum przytoczonej materii językowej. Zazwyczaj tłumaczono tylko frazy najbardziej przypominające europejskie przysłowia, natomiast tutaj autor daje różne typy „fraz gotowych”, określanych po chińsku jako chengyu, a obok nich także innego typu całostki frazeologiczne, i to na wiele tematów oraz z rozmaitych źródeł. Autor pogrupował je w kilka działów: natura człowieka, zdobywanie wiedzy, natura świata, przeznaczenie, historia Chin, słynne passusy z powieści klasycznych, fragmenty znanych utworów poetyckich oraz pieśni, przysłowia ludowe, i wreszcie „słowa godne zapamiętania”. Wyraźnie kierował się przy takim ujęciu bardziej obyczajami chińskimi niż polskimi.

Już na wstępie autor zapowiada, że przedstawia najpiękniejsze sentencje, czyli dobrał je w sposób dowolny, wedle własnego upodobania. Znajdzie więc tam czytelnik powiedzenia zarówno powszechnie znane, jak i rzadkie. Łącznie pra- 
ca prezentuje 81 takich fraz wybranych z kilkudziesięciu tysięcy! Każdy rozdział poprzedza krótkie wprowadzenie kulturowe. Czasem autor dodaje jeszcze objaśnienia kulturowe „w ramce” jako wyodrębniony tekst. Pewne specjalistyczne wyjaśnienia pojawiają się w przypisach. Objaśnienia „w ramce” dotyczą różnych koncepcji, pojęć, zdarzeń czy przedstawienia znaczących osób, a jest ich łącznie koło trzydziestu. Jest to więc swoisty almanach rozmaitości wszelakich na temat chińskiego dziedzictwa literackiego, intelektualnego, a pośrednio także historycznego, kopalnia wiedzy o tradycjach chińskich, często z odniesieniami do współczesności. Ogromnie dużo można się z tej pracy dowiedzieć o Chinach, a zawarta w niej wiedza nie jest banalna, odbiega od stereotypów oraz schematów dziennikarskich. Widać, że autor jest koneserem i miłośnikiem kultury chińskiej, a także utalentowanym przewodnikiem po niej. Umie opowiadać o różnych sprawach krótko, treściwie i zajmująco. Na ogół czyni to też kompetentnie.

$\mathrm{Na}$ specjalne omówienie zasługuje wyjątkowo wysmakowana szata graficzna książki, którą w pełni doceni przede wszystkim znawca kultury chińskiej. Taka dbałość wydawnictwa o wygląd publikacji jest u nas zjawiskiem niezmiernie rzadkim. Już sama okładka - sztywna, ale przyjemna w dotyku, w kolorze czerwonym, z chińskimi wzorami w barwie starego złota - sugeruje, że mamy do czynienia z czymś cennym, co jest - albo może być - eleganckim podarkiem (w Chinach podarki pakuje się właśnie na czerwono!). Wewnątrz znajdziemy, wykonane na dobrym papierze i z rozmaitymi drobnymi ozdobami graficznymi, ryciny i inskrypcje hieroglificzne przygotowane specjalnie dla tej pracy przez artystów z Tajwanu, gdzie autor obecnie mieszka. Są także fragmenty reprodukcji dawnych dzieł malarskich oraz barwne fotografie ze współczesnych Chin oraz Tajwanu (niestety, bez podania ich autora!), jak też barwne i estetycznie opracowane mapki państw chińskich z różnych epok przywoływanych w tekście. Nawet barwa druku na stronie została zróżnicowana i często pojawiają się czerwone przerywniki.

Jest to zatem praca na poziomie akademickim, chociaż zarazem ma charakter popularnego wprowadzenia do tematu kultury chińskiej - duchowej i językowej, w dodatku kultury żywej, gdyż ukazuje, jak dawne dziedzictwo funkcjonuje współcześnie w społecznościach chińskich (w tym przypadku głównie na nader zmodernizowanym i zamerykanizowanym Tajwanie). Napisana jest przystępnym językiem, zajmująco i dość lekko. Specyfikę kultury chińskiej zazwyczaj autor opisuje trafnie i dość precyzyjnie, choć oczywiście pewne stwierdzenia autora mogą być dyskusyjne.

Pracę uzupełniają na końcu różne aneksy: a) alfabetyczny indeks sentencji (wg transkrypcji chińskiej, z zapisem łacińskim i hieroglificznym); b) indeks polskich przekładów sentencji; c) indeks fotografii i reprodukcji malarstwa; d) indeks map i ramek informacyjnych; e) objaśnienie o chińskim systemie datowania historycz- 
nego; f) chronologia chińskich okresów historycznych (często przywoływanych w tekście); g) polskie przekłady tekstów źródłowych.

Czy w tej bardzo użytecznej i pięknie wydanej pracy nie ma potknięć? Oczywiście są i to różnego rodzaju. Przede wszystkim tłumaczenia powiedzeń chińskich bywają czasem ,przegadane”, podczas gdy uroda oryginału chińskiego zasadza się na lapidarności. Np. powiedzenie shi nian shu mu, bai nian shu ren autor thumaczy: „By drzewo wyrosło trzeba dziesięciu lat, aby człowiek został wykształcony potrzeba stu lat" (s. 53). To oddaje dobrze sens, ale zawiera aż trzynaście słów, podczas gdy oryginał chiński ma ich osiem! Bliższe oryginałowi byłoby: Drzewo wyrasta $\mathrm{w}$ dziesięć lat, człowiek formuje się przez sto lat. Inną ośmiosylabową frazę ze specyficznymi powtórzeniami i grą słów Huijia bu mang, mangjia bu hui autor książki tłumaczy: „Znający się na rzeczy nie są zapracowani, zaś ci zajęci nie wiedzą, jak należy rzecz wykonać" (s. 55). Taki jest istotnie sens, ale chyba lepszy byłby przekład: Mistrz nie jest zapracowany, zapracowany nie jest mistrzem; czy bardziej dosłowny: Kto umie, nie jest zapracowany; kto jest zapracowany - nie umie!

W innych przypadkach autor zdaje się chyba przyjmować założenie, że tłumaczenie powiedzenia chińskiego musi być jasne i jednoznaczne, podczas gdy oryginał chiński bywa wieloznaczny albo nawet niezrozumiały bez przytoczenia historyjki, z której się wywodzi. Czterosylabowe powiedzenie bu chi xia wen autor oddaje jako: „Nie wstydź się zasięgać rady u niżej stojących” (s. 61), co jest zdaniem dwa razy dłuższym. Można by to zaś oddać: Nie wstyd pytać (albo radzić się) podwładnych. Trudno też zaakceptować przekład frazy san ren cheng hu - ,[Wieść powtórzona przez] trzech ludzi czyni [zmyślonego] tygrysa [prawdziwym]" (s. 85). Przekład czterosylabowca z trzema wstawkami w nawiasach kwadratowych to morderstwo popełnione na tej frazie. I ponownie, dążąc do przekazania pełnego sensu, autor wyraźnie przedobrzył. Istotnie, trudno to oddać lapidarnie i sens frazy chińskiej jest mało zrozumiały. Lepiej chyba było zachować tę niejasność i dać przekład prawie dosłowny: już trzech ludzi tworzy/potwierdza istnienie tygrysa. A w objaśnieniu można było przekazać, że powtórzenie plotki przez kilku ludzi niesłusznie uwiarygodnia ją w umyśle odbiorcy. Cała historyjka przytoczona przez autora dobrze wyjaśnia sens. Zdarzają się też przekłady nieścisłe. She gong hao long autor tłumaczy: „Wspaniałe smoki księcia She” (s. 41). Po chińsku jest to: upodobanie/zamiłowanie do smoków księcia She. Znacznie lepsze przekłady autor, nie wiadomo dlaczego, podaje w przypisie: „Zamiłowanie księcia She do smoków". Nie chodzi w tym powiedzeniu zupełnie o to, jak wspaniałe były smoki zbierane przez niego (a raczej ich malunki), lecz o to, że jego zamiłowanie było powierzchowne, pozorne, było tylko rodzajem zabawy. Natomiast wtedy, gdy przybył do niego prawdziwy smok, przestraszył się go śmiertelnie. 
Innym mankamentem, który należało usunąć w pracy redakcyjnej jest częste podawanie nazw chińskich w mianowniku, podczas gdy powinny być one odmieniane przez przypadki. Fraza „dzieje trzech przyjaciół Liu Bei, Guan Yu, Zhan Fei...” (s. 79) po prostu razi po polsku. Podpis pod fotografią „Noc nad jeziorem Xihu w mieście Hangzhou" (s. 100) nasuwa wątpliwości innego rodzaju. Przede wszystkim nazwę tego sławnego jeziora zazwyczaj tłumaczy się na polski jako Jezioro Zachodnie ( $X i$ - to zachód, zachodni, $h u$-jezioro). Uchodzi ono od stuleci za jedno z najpiękniejszych miejsc Chin i można coś było o tym dodać. Nie powinno się też z zasady robić powtórzenia po polsku i chińsku i pisać ,jezioro xxhu". Pisząc o górach (s. 210), autor prawidłowo pisze Góra Tai (a nie Góra Taishan, bo shan to góra). Zdanie o legistach, że to ,przedstawiciele szkoły filozofii w chińskiej filozofii" (s. 120) jest oczywistym potknięciem redakcyjnym. Nie mówimy też o „piśmie małej pieczęci” (s. 121), tylko o „małopieczęciowym”.

Czasem drobne potknięcia pojawiają się w objaśnieniach w ramce. Junzi - to nie jest „syn książęcy” (s. 46). W języku klasycznym sam termin jun oznaczał władcę państwa i feudałów wszystkich rang mających swoje choćby najmniejsze władanie ziemskie. $Z i$ ma zaś wiele znaczeń, nie tylko tłumaczy się jako „syn”. Termin junzi oznaczał po prostu arystokratę, w terminologii konfucjańskiej - „męża szlachetnego", czy szerzej - osobę wielkich cnót i/lub dużej wiedzy. Bywa też, że całe zastosowane objaśnienie budzi wątpliwości. Np. jedno z nich nosi tytuł „Znak pisma chińskiego long" (s. 94) z podaniem hieroglifu w miejsce użytej tu transkrypcji i z pięknym kaligraficznie wypisanym znakiem u góry. Po dwu ogólnikowych zdaniach przytoczona jest ewolucja powstania graficznej formy tego znaku. Takie objaśnienie jest w istocie mało zrozumiałe dla osoby nieznającej chińskiego. Należało dać po prostu tytuł "Smok” i podać szerszy opis znaczenia smoka w kulturze chińskiej. Przede wszystkim wskazać, że tam jest to istota szlachetna, dobroczynna, przynosząca deszcze, a nie złowrogi potwór, którego się zabija, jak w odbiorze europejskim. Do tego można było oczywiście dodać etymologię znaku od wyobrażeń piktograficznych. Byłoby to tym bardziej użyteczne, że smok jest wspominany przy powiedzeniach i stanowi jeden $\mathrm{z}$ istotnych symboli $\mathrm{w}$ kulturze chińskiej. Przeglądając spis tych objaśnień i je same, odnosi się wrażenie pewnej przypadkowości i braku jasnej koncepcji, jaki był klucz ich doboru.

Dyskusyjne są również pewne kwestie terminologiczne. Autor podstawowe terminy konfucjańskie tłumaczy na sposób przyjęty tradycyjnie w Katedrze Sinologii na Uniwersytecie Warszawskim. Oczywiście trudno mu z tego czynić zarzut. Jednak myślę, że nadszedł czas, aby te tłumaczenia przemyśleć na nowo, zwłaszcza, że utrwaliły się znacznie lepsze ich tłumaczenia angielskie. Na przykład konfucjański termin ren - tu thumaczony jako „humanitaryzm” lub „miłosierdzie” (s. 76) - oddaje się zwykle o wiele trafniej przez benevolence, czyli życzliwość, dobroć. 
Podobnie xiao - „nabożność synowska” (s. 81) Polakowi kojarzy się raczej z pobożnością niż z czcią dla rodziców i gorliwym służeniem im.

Jak widać, poza sprawą thumaczeń niektórych powiedzeń oraz doboru objaśnień, są to w istocie sprawy drugorzędne, które należy odnotować z obowiązku recenzenta i do ewentualnych poprawek w drugim wydaniu. Książka jest bowiem bardzo wartościowa i piękna. 